\title{
A STUDY ON WEED CONTROL IN SOYBEAN
}

\author{
S. TJITROSEMITO \\ Tropical Agricultural Pest Biology Programme, SEAMEO BIOTROP, Bogor, Indonesia
}

\begin{abstract}
Two field experiments on weed control in soybeans were carried out at BIOTROP, Bogor, Indonesia from February to June, 1989. The critical period for weed control was found to be between 20 - 40 days after planting of soybean (c. v. Wilis) grown at a planting distance of $40 \times 10 \mathrm{~cm}$. It did not coincide with the fastest growth in terms of trifoliate leaf number. Further studies were suggested to understand the physiological growth of soybean related to weed control.

Pendimethalin at 660- $1320 \mathrm{~g}$ a.e./ha applied one day after sowing did not cause any phytotoxic effect to soybean and had good weed control performance.
\end{abstract}

\section{INTRODUCTION}

With the establishment of the Soybean Yield Gap Analysis Project (SYGAP) in Indonesia (Douphin et al. 1986), about 34.5 million ha were identified to be suitable for soybean planting (Pasaribu \& Mclntosh 1986). It was assumed, therefore, that it was adequate area-wise but when yield/ha was considered, it was still very low (0.7-0.8 ton/ha; Somaatmadja 1983). This low yield may be attributed to various factors like (1) poor stand, (2) poor growth, (3) weed problems, (4) excess water, (5) empty pods due to insect damage or drought (Pasaribu \& Mclntosh 1986).

Fachurrozi et al. (1988) surveyed the production system of soybean at farmers level in East Java (district of Pasuruan). They reported that weeding was the most labour intensive operation. It took $51 \%$ and $65 \%$ of the total work hours and $32 \%$ and $34 \%$ of the total cash production costs in two villages of Oro-Oro Pule and Sumberbanteng. However, although the cost of weeding was high, their studies indicated that yield could be increased by controlling weeds, pests and diseases. Twice weeding resulted in marginal rates of return (MRR) of 118 - 147\%, whereas MRR of controlling pests and diseases was 1012 - 1454\%. These figures showed how beneficial the control of "pests" (insect, pathogens, weeds, vertebrate pests) was.

Recent work indicated that soybean crops planted at various planting distances from $30 \times 10 \mathrm{~cm}$ to $40 \times 20 \mathrm{~cm}$ could tolerate infestation of weeds up to $30 \%$ of SDR (Tjitrosemito 1987). The growth of soybean was, however, not optimal as was also reported by Pasaribu and Mclntosh (1986).

In this context, it is appropriate to emphasize that weed control (weed management) is an integral part of the whole production management. The success of weed control is to be judged also from its ability to increase yield with sufficient profit. 
BIOTROPIA No. 4, 1990/1991

\section{MATERIAL AND METHODS}

\section{Experiment 1}

A field experiment was conducted at BIOTROP, Bogor from November 1988-February 1989 to determine the critical period of weed control on soybean crops (c.v. Wilis). Fourteen treatments consisting of various manual control schemes were applied in plots measuring $4 \times 5 \mathrm{~m}^{2}$ replicated $3 \mathrm{x}$ with randomized block design.

The fourteen treatments were:

1. Manual weed control from planting up to 10 days after planting (DAP)

2. Manual weed control from planting up to 20 DAP

3. Manual weed control from planting up to 30 DAP

4. Manual weed control from planting up to 40 DAP

5. Manual weed control from planting up to 50 DAP

6. Manual weed control from planting up to 60 DAP

7. Manual weed control from planting up to harvest

8. Manual weed control from 10 DAP to harvest

9. Manual weed control from 20 DAP to harvest

10. Manual weed control from 30 DAP to harvest

11. Manual weed control from 40 DAP to harvest

12. Manual weed control from 50 DAP to harvest

13. Manual weed control from 60 DAP to harvest

14. No weeding at all.

The plots were manually cultivated before planting and fertilized at the rate of 45 $\mathrm{kg} \mathrm{N} / \mathrm{ha}, 50 \mathrm{~kg} \mathrm{P}_{2} \mathrm{O}_{5} / \mathrm{ha}$ and $50 \mathrm{~kg} \mathrm{~K}_{2} \mathrm{O} / \mathrm{ha}$, applied by broadcasting along the planting rows. The planting distance was $40 \times 10 \mathrm{~cm}$. Insect pest control was done by spraying Azodrin $60 \mathrm{WSC}$ at $2 \mathrm{ml} / \mathrm{It}$ solution; while Dithane M-45 at $2 \mathrm{~g} / 1$ was used against pathogens.

The soybean was harvested at 98 DAP; and the yield was compared statistically using LSD at $5 \%$. Weeds were sampled before harvest using a quadrat of $50 \times 50 \mathrm{~cm} 2 \mathrm{x}$ in each plot. The growth of soybean was recorded in terms of trifoliate leaf number.

\section{Experiment 2}

Another field experiment was also conducted at BIOTROP from March-June, 1989. There were 12 treatments applied in plots measuring $2.5 \times 10$ m replicated $3 \mathrm{x}$ in a randomized block design. This experiment was a repetition of 
the one of previous year, since some herbicidal treatments showed high crop mortality.

The treatments were:

1. Untreated plot

2. Imazethapyr (I)

3. Imazethapyr (I)

4. Imazethapyr (I)

5. Imazethapyr (I)

6. Imazethapyr (I)

7. Pendimethalin (P)

8. Pendimethalin (P)

9. $\mathrm{P}+1$

10. $\mathrm{P}+1$

11. Alachlor

12. Manual weeding

: pre-emergence

: pre-emergence

: pre-emergence

: pre-emergence

: early post

: pre-emergence

: pre-emergence

: pre-emergence

: pre-emergence

: pre-emergence

: at 3 and 6 weeks
: $50 \mathrm{~g}$ a.e./ha

: 75 g a.e./ha

: $100 \mathrm{~g}$ a.e./ha

: $150 \mathrm{~g}$ a.e./ha

: $100 \mathrm{~g}$ a.e./ha

: $660 \mathrm{~g}$ a.e./ha

: 1320 g a.e./ha

: $660+50$ g a.e./ha

$: 1320+50$ g a.e./ha

: $1440 \mathrm{~g} \mathrm{a.i/ha}$

The spraying of herbicides was done using a CP - 15 knapsack sprayer, calibrated to deliver 4001 solution/ha, using yellow nozzle at high pressure. The pre-emergence spraying was done one day after planting.

The samplings were carried out using a quadrat measuring $50 \times 50 \mathrm{~cm}^{2}$.

The plots were manually cultivated and fertilized with $60 \mathrm{~kg} \mathrm{P}_{2} \mathrm{O}_{5} / \mathrm{ha} ; 45 \mathrm{~kg} \mathrm{~N} / \mathrm{ha}$ and $50 \mathrm{~kg} \mathrm{~K}_{2} \mathrm{O}_{5} /$ ha at planting time, broadcast along the soybean row. To prevent damage to seedlings of $O$. phaseoli, furadan was utilized.

The soybean was harvested at 98 days after planting.

\section{RESULTS AND DISCUSSION}

The soybean yield from experiment $\mathrm{I}$ is shown in Table 1.

When expressed in the graph (Figure 1) it indicates that the critical period of weed control is between 20 and 40 DAP.

Lengthening the weed free period from 10 to 40 DAP increased the yield i.e. from 0.62 ton/ha to 1.36 ton/ha, but further lengthening the period of control did not increase the yield any more.

Leaving the field unweeded for a period of 10 - 20 DAP did not really matter, but leaving more than 20 days unweeded reduced the yield considerably i.e. from 1.54 ton/ha to 1.33 ton/ha. When weeding was done only 40 DAP the yield was further reduced.

The weed infestations were presented in Table 2 (weed count) and Table 3 (dry weight). The infestations of Borreria alata, Ageratum conyzoides, Eleutheran- 
Table 1 . The mean yield of soybean at various control schemes

\begin{tabular}{|c|c|c|c|}
\hline & Treatment & & ton/ha \\
\hline 1. & Weeded up to 10 days & after planting (DAP) & 0.62 \\
\hline 2. & Weeded up to 20 DAP & & 0.92 \\
\hline 3. & Weeded up to 30 DAP & & 1.25 \\
\hline 4. & Weeded up to 40 DAP & & 1.36 \\
\hline 5. & Weeded up to 50 DAP & & 1.36 \\
\hline 6. & Weeded up to 60 DAP & & 1.35 \\
\hline 7. & Weeded up to harvest & & 1.50 \\
\hline 8. & Weeded from 10 DAP & to harvest & 1.50 \\
\hline 9. & Weeded from 20 DAP & to harvest & 1.54 \\
\hline 10. & Weeded from 30 DAP & to harvest & 1.33 \\
\hline 11. & Weeded from 40 DAP & to harvest & 1.26 \\
\hline 12. & Weeded from 50 DAP & to harvest & 1.05 \\
\hline 13. & Weeded from 60 DAP & to harvest & 0.85 \\
\hline \multirow[t]{3}{*}{14.} & No weeding at all & & 0.65 \\
\hline & $\operatorname{LSD}(5 \%)$ & & 0.14 \\
\hline & $\mathrm{CV}$ & & $10 \%$ \\
\hline
\end{tabular}

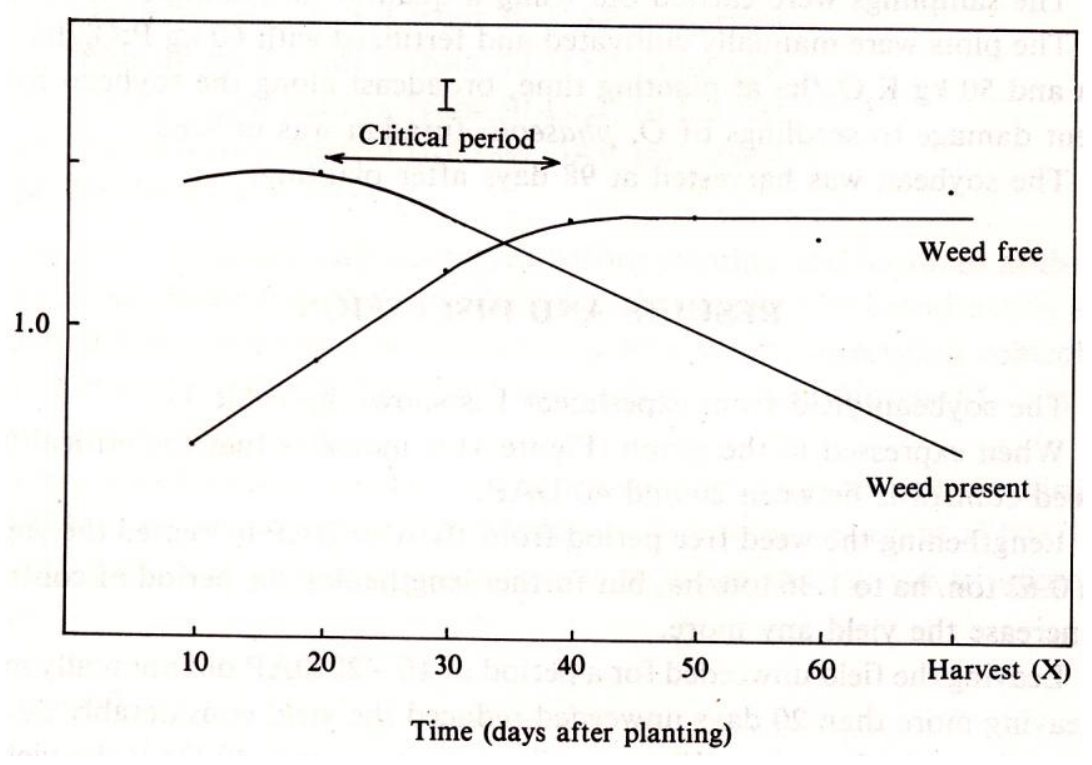

Figure 1. The effect of "weed free" and "weed present" periods on yield of soybean. The critical period appeared to be between 20-40 DAP. 
A study on weed control in soybean-S. Tjitrosemito

Table 2. Mean weed count $/ 50 \times 50 \mathrm{~cm}^{2}$ at various weeding schemes (average of 3 blocks)

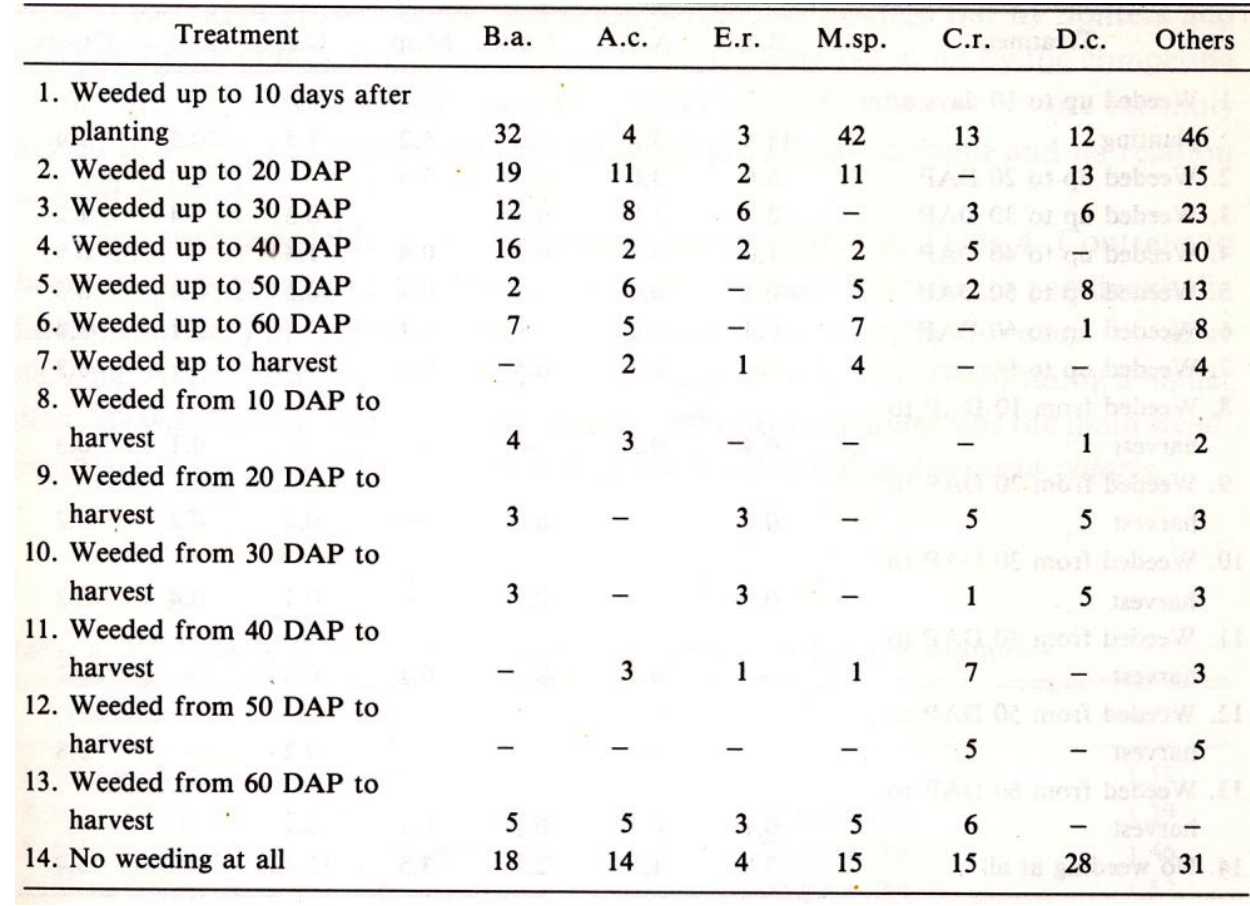

B.a. : Borreria alata (Aubl.) DC

A.c. : : Ageratum conyzoides $L$.

E.r. : Eleutheranthera ruderalis $S c h$.

M.sp. : Mitracarpus sp.

C.r. $\quad$ : Cyperus rotundus $L$.

D.c. : Digitaria ciliaris (Retz) Koel.
Others include : Celosea argantea

Leucas lavandosalia

Stachytarpheta jamaicensis

Euphorbia geniculata

Oxalis sp.

Phyllantus niruri L.

Cleome rutidospermum DC.

Emelia sonchifolia

Tridax procumbens

Eleusine indica

thera ruderalis, Digitaria ciliaris, and to some degree also Cyperus rotundus were considerable when not weeded and they constituted the main weeds in the area.

The growth performance of soybean is presented in Figure 2. Early in the growth stage, the growth was slow especially in the first 2-3 weeks in terms of leaf number. This was the period when the presence of weeds was not felt by the crops. From 3 to 6 weeks (20 - 40 DAP) the growth was still slow compared to the period between 40 to 60 days when growth was from 9 to 16 leaves/plant. However, at 60 DAP, the crop started to shed the leaves and the number of leaves went down. 
BIOTROPIA No. 4, 1990/1991

Table 3. Mean dry weight of weed grains $/ 50 \times 50 \mathrm{~cm}^{2}$ at various weeding schemes (Average of 3 blocks)

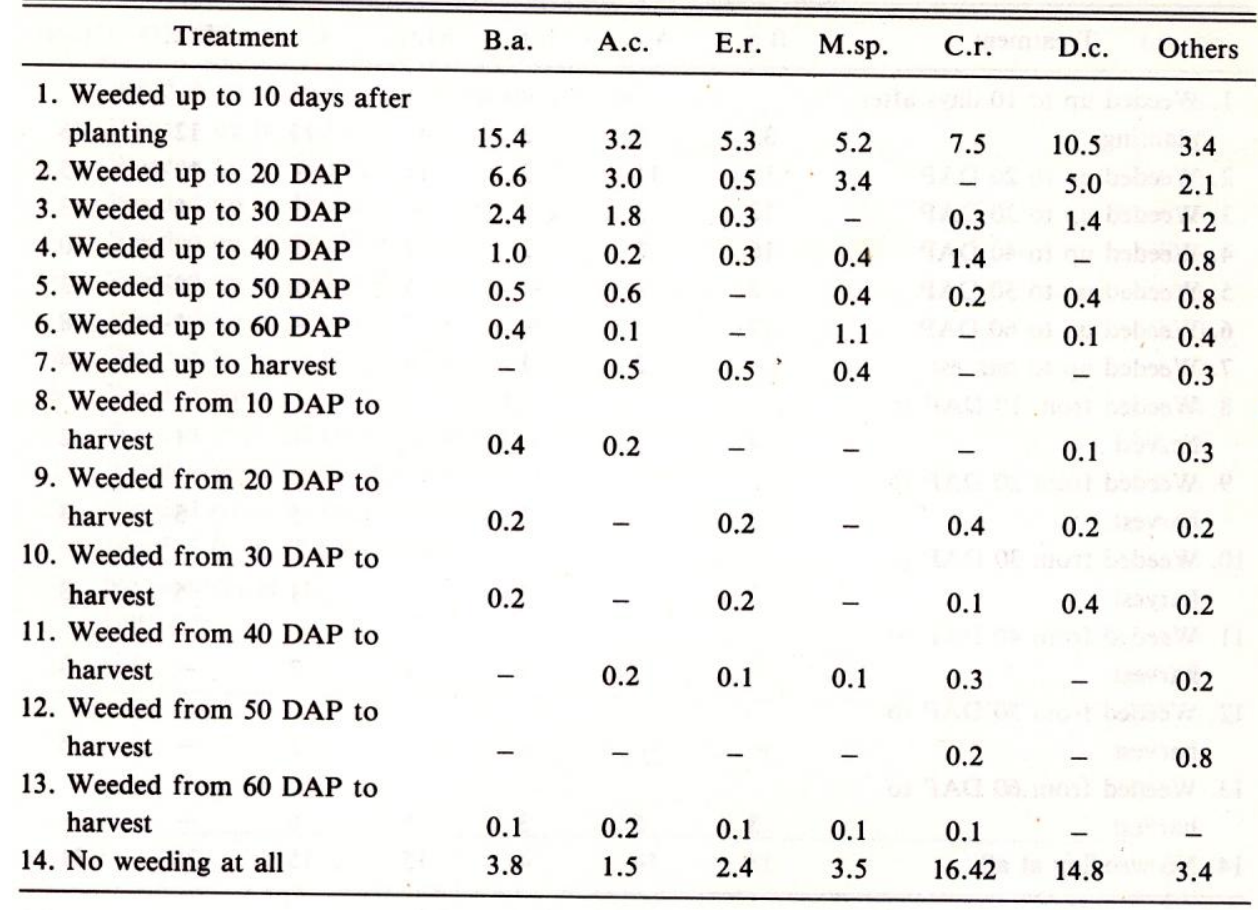

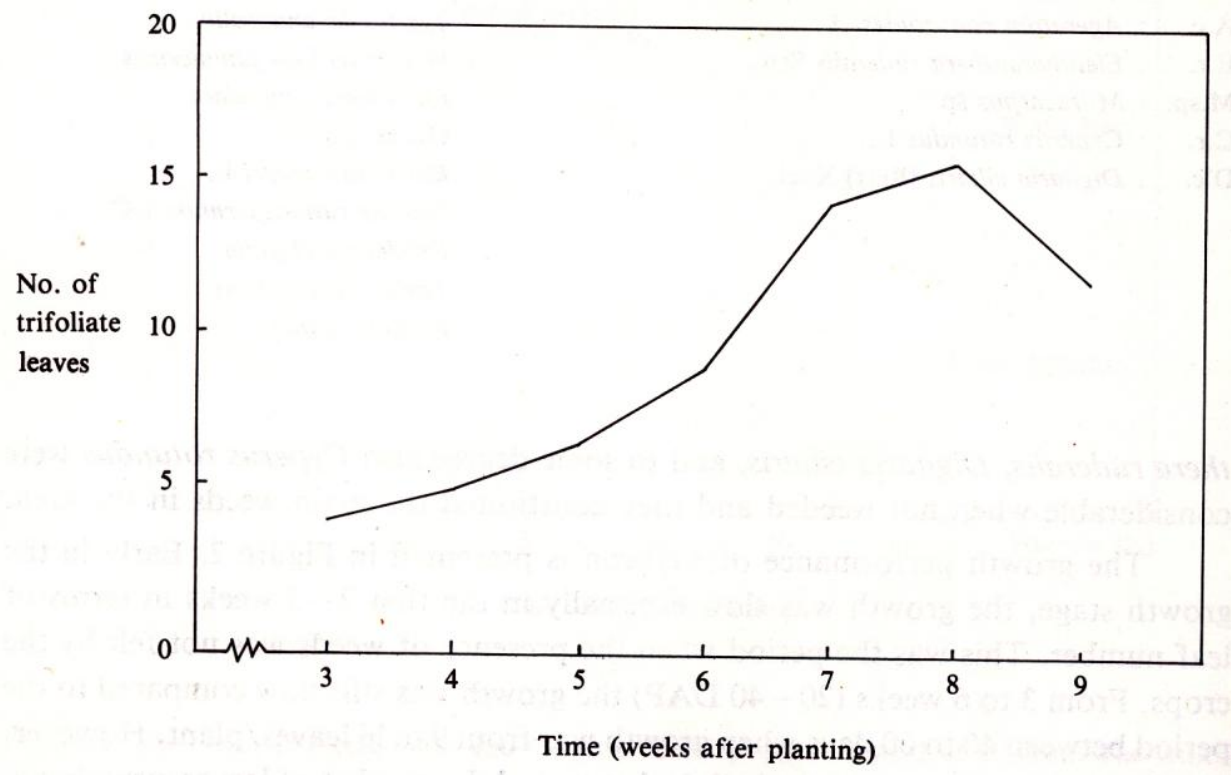

Figure 2. The growth performance of soybean (c.v. Wilis) in terms of number of trifoliate leaves. 
Probably, availability of resources in the period of 20 - 40 DAP was necessary to support the rapid growth in the following period. As pointed out by Spitters and Van den Bergh (1982), once nutrients or moisture were taken up by the competing weeds, they were not available anymore to the crop. Further works are certainly needed to really understand the physiological growth of soybean and its relation to weed control

The soybean yields in the experiment are presented in Table 4. Contrary to the result of the previous year (Tjitrosemito 1988) soybean treated with pendimethalin did not show any phytotoxicity with the pre-emergence spraying done one day after planting. At the same time, the control of weed was better, thus facilitating a higher yield. As was reported earlier (Tjitrosemito 1988) Borreria alata was the main weed. Pendimenthalin at $1320 \mathrm{~g}$ a.e./ha was good in controlling Digitaria ciliaris.

Table 4. The mean of soybean yield (ton/ha) under various weed control treatments

\begin{tabular}{|c|c|c|c|}
\hline Treatment & & & ton/ha \\
\hline 1. Untreated plot & & & 1.18 \\
\hline 2. Imazethapyr (I) & : pre-emergence & : $\quad 50 \mathrm{~g}$ a.e. $/ \mathrm{ha}$ & 1.29 \\
\hline 3. Imazethapyr (I) & : pre-emergence & : $\quad 75 \mathrm{~g}$ a.e. $/ \mathrm{ha}$ & 1.46 \\
\hline 4. Imazethapyr (I) & : pre-emergence & : $100 \mathrm{~g}$ a.e. $/ \mathrm{ha}$ & 1.52 \\
\hline 5. Imazethapyr (I) & : pre-emergence & : $150 \mathrm{~g}$ a.e. $/ \mathrm{ha}$ & 1.60 \\
\hline 6. Imazethapyr (I) & : early post & : 100 g a.e. $/ \mathrm{ha}$ & 1.53 \\
\hline 7. Pendimethalin (P) & : pre-emergence & : $660 \mathrm{~g}$ a.e. $/ \mathrm{ha}$ & 1.60 \\
\hline 8. Pendimethalin (P) & : pre-emergence & : $1320 \mathrm{~g}$ a.e. $/ \mathrm{ha}$ & 1.45 \\
\hline 9. $P+1$ & : pre-emergence & $: 660+50 \mathrm{~g}$ a.e. $/ \mathrm{ha}$ & 1.68 \\
\hline 10. $P+1$ & : pre-emergence & $: 1320+50 \mathrm{~g}$ a.e. $/ \mathrm{ha}$ & 1.50 \\
\hline 11. Alachlor & : pre-emergence & : $1.440 \mathrm{~kg}$ a.i. $/ \mathrm{ha}$ & 1.68 \\
\hline \multirow[t]{3}{*}{ 12. Manual weeding } & & & 1.84 \\
\hline & & $\operatorname{LSD}(5 \%)$ & 0.20 \\
\hline & & $\mathrm{CV}$ & $10 \%$ \\
\hline
\end{tabular}

\section{REFERENCES}

DAUPHIN, F., J.W.T. BOTTEMA and A. RACHIM. 1986. Soybean yield constraints, socio-economics or Technologic. Palawija News III (2): 1-2.

FACHRURROZ, Q. J. LAUMANS and R. KRISDIANA. 1988. Production economic aspects of soybean grown on legal: A case study in Pasuruan District East Java. Penelitian Palawija 3 (2): 105-115. S

OMAATMADJA, S. 1983. Development of soybean culture in Indonesia In: International Symposium on Soybean in the Tropics and Substropics. Tropical Research Center, Ministry of Agriculture, Forestry and Fishery Japan. Tropical Agricultural Research Series No. 17: 23-35. 
BIOTROPIA No. 4, 1990/1991

PASARIBU and Me. INTOSH. 1986. Soybean production in Indonesia. Soybean in Tropical and Subtropical Cropping Systems. Proc. Symp. Tsukuba, Japan 26 Sept.- 1 Oct. 1983. AVRDC: 1-11.

SPITTERS, C.J.T. and J.P. VAN DEN BERGH. 1982. Competition between crop and weeds. A system approach In: Holzner and Numata (eds) Biology and Ecology of Weeds: 137-148.

TJTROSEMITO, S. 1987. Threshold level of weed control in soybean crop for small farmers. Proc. Xlth APWSS Conf. I: 247-258.

, 1988. Weed control on soybean crop using imazethapyr. Paper presented to the Second Trop. Weed Conf. Phuket, Thailand. December 6-10, 1988. 